\title{
Realitas Sosial pada Masa Pandemi dalam Cerpen Atai Balak dan Rencana Lebaran Korona (Social Reality during a Pandemic in the short story of Atai Balak dan Rencana Lebaran Corona)
}

\section{Septina Krismawatia, ${ }^{\mathrm{a}}$}

${ }^{\mathrm{a}, 1}$ Universitas Sanata Dharma, Yogyakarta, Indonesia septina.krisma@gmail.com

\begin{tabular}{ll}
\hline Article info & A B S T R A C T \\
\hline Article history: & This study aims to describe the social reality during the pandemic \\
Revised : 10-04-2021 & that appears in the short stories Atai Balak dan Rencana Lebaran \\
Accepted: 19-05-2021 & Corona. This qualitative descriptive research analyzes social \\
& reality with a sociological approach to literature. Data collection \\
& is done by listening and note-taking techniques. Data analysis was \\
& done by using the content analysis method and the sociology of \\
& literature approach. The results of the study show that 1) this short \\
& story can be a reflection of reality during a pandemic, 2) the life of \\
& the lower class community during a pandemic is represented in Atai \\
& Balak as the main character, and 3) social reality during a \\
& pandemic that can be found in the short story, namely related to the \\
& policy of Large-Scale Social Restrictions and the reality of \\
& increasing poverty.
\end{tabular}

Keywords:

Atai Balak dan Rencana Lebaran Corona sociology of literature approach pandemic

Penelitian ini bertujuan untuk mendeskripsikan realitas sosial pada masa pandemi yang tampak pada cerpen Atai Balak dan Rencana Lebaran Korona. Penelitian deskriptif kualitatif ini menganalisis realitas sosial dengan pendekatan sosiologi sastra. Pengumpulan data dilakukan dengan teknik simak dan teknik catat. Analisis data dilakukan dengan metode analisis isi dan pendekatan sosiologi sastra. Hasil penelitian menunjukkan bahwa 1) cerpen ini dapat menjadi cerminan kenyataan pada masa pandemi, 2) kehidupan masyarakat kalangan bawah pada masa pandemi terepresentasi pada diri Atai Balak sebagai tokoh utama, dan 3) realitas sosial pada masa pandemi yang dapat ditemukan dalam cerpen tersebut, yaitu terkait dengan kebijakan Pembatasan Sosial Berskala Besar (PSBB) dan realitas kemiskinan yang semakin meningkat.

Copyright (C) 2021 Institut Agama Islam Negeri Syekh Nurjati Cirebon. All rights reserved.

\section{PENDAHULUAN}

Sejak sekitar bulan Maret 2020, negara Indonesia menghadapi sebuah permasalahan yang sangat berat, yaitu adanya pandemi Corona Virus Disease 2019 (Covid-19). Pandemi ini sebenarnya tidak hanya membawa persoalan bagi negara Indonesia, tetapi juga negara-negara lain. Berbagai persoalan sosial muncul akibat adanya pandemi ini. Bagi negara Indonesia sendiri, pandemi ini mengakibatkan lumpuhnya ekonomi nasional sehingga tidak sedikit orang yang kehilangan mata pencaharian. Persoalan sosial yang timbul akibat pandemi ini menjadi sorotan banyak pihak. Setiap hari sejak bulan Maret 2020 hingga saat ini berbagai media selalu menampilkan pemberitaan tentang Covid-19. Selain berbagai pemberitaan tentang Covid-19, berbagai media massa, baik cetak maupun elektronik, yang 
biasanya menghadirkan rubrik sastra pun, mulai menampilkan karya-karya sastra seputar pandemi ini dari berbagai penulis atau sastrawan.

Hal tersebut, salah satunya dapat ditemukan pada media massa elektronik, yaitu JawaPos.com, salah satu media yang cukup memiliki eksistensi di Indonesia dengan cakupan pembaca yang luas. Pada tanggal 31 Mei 2020, JawaPos.com memuat sebuah cerpen berjudul Atai Balak dan Rencana Lebaran Korona. Cerpen ini ditulis oleh Guntur Alam, seorang penulis muda dari Sumatera Selatan yang karya-karyanya telah banyak terpublikasi di berbagai media massa nasional. Dalam cerpen ini, Guntur Alam menghadirkan sebuah permasalahan sosial yang terjadi akibat pandemi covid-19.

Penulisan cerpen Atai Balak dan Rencana Lebaran Korona yang secara khusus menghadirkan permasalahan sosial sebagai potret pandemi yang saat ini sedang terjadi, tentu saja didasari oleh alasan yang kuat. Permasalahanpermasalahan sosial dalam karya sastra dapat dijadikan cerminan atas peristiwaperistiwa yang terjadi dalam kehidupan nyata. Hal ini sesuai dengan pendapat Emzir \& Rohman (2015) yang menyatakan bahwa sastra mengisyaratkan gambaran hidup manusia yang kompleks. Karya sastra merupakan kiasan dari realitas kehidupan. Representasi kehidupan masyarakat dapat ditemukan dalam cerpen. Hal itu dapat dijadikan refleksi bagi pembaca cerpen akan realitas kehidupan yang cukup kompleks tersebut.

Akan tetapi, pada kenyataannya, menemukan realitas sosial dalam cerpen Atai Balak dan Rencana Lebaran Korona yang diharapkan dapat menjadi refleksi atas pandemi yang saat ini terjadi seperti disinggung di atas, tidaklah mudah. Cerpen yang dicipatakan oleh seorang pengarang dengan makna yang tersirat sering menyulitkan pembaca dalam menangkap makna yang ada pada cerpen itu. Selain itu, kompleksitas berbagai unsur yang membangun cerpen juga semakin menyulitkan pembaca dalam mengungkapkan makna yang terdapat dalam cerpen (Mulyaningsih, 2015). Di sinilah tampak bahwa terdapat sebuah permasalahan untuk dapat menangkap dan mengungkap makna secara tepat yang berupa realitas sosial dalam cerpen Atai Balak dan Rencana Lebaran Korona. Dibutuhkan sebuah analisis secara mendalam untuk mengungkap realitas sosial dalam cerpen itu secara tepat.

Untuk dapat mengungkap realitas sosial tersebut dibutuhkan sebuah teori dan pendekatan yang tepat. Pendekatan sosiologi sastra yang dipilih sebagai pisau analisis mampu menjawab kebutuhan tersebut. Jabrohim (2014) memaparkan bahwa sastra bukanlah suatu karya yang otonom dan berdiri sendiri. Karya sastra selalu terikat dengan kondisi sosial budaya tempat karya tersebut dihasilkan. Dalam pernyataan tersebut tersirat juga sebuah kenyataan yang tidak dapat dimungkiri bahwa pengarang yang memproduksi karya sastra sebenarnya merupakan bagian dari anggota masyarakat. Lebih lanjut Jabrohim (2014) menyebutkan juga bahwa sosiologi sastra mempertimbangkan segi-segi kemasyarakatan oleh beberapa penulis. Sosiologi sastra dapat dapat dijabarkan ke dalam beberapa pokok bidang sasaran. Pertama, konteks sosial sastrawan. Kedua, sastra sebagai cermin masyarakat. Ketiga, fungsi sosial sastra.

Sebagai sebuah kajian interdisipliner, sosiologi sastra akan berkaitan dengan sosiologi sebagai salah satu bidang ilmu sosial (Bruce, 2018) dan juga sastra yang banyak didefinisikan sebagai karya fiksi (Canton, 2016). Kajian sosiologi sastra akan selalu melihat karya sastra dalam hubungannya dengan kondisi sosial yang 
melingkupinya (Abrams \& Harpham, 2011). Hal itu didasarkan pada sebuah argumen bahwa sebuah karya sastra mampu merepresentasikan berbagai peristiwa yang dipaparkan secara sistematis dengan berdasarkan pada metode sosiologi (Wahyudi, 2013).

Dari paparan tersebut, jelas sekali bahwa kajian sosiologi sastra sangat tepat untuk digunakan dalam menganalisis realitas sosial yang terdapat pada karya sastra. Dengan kajian sosiologi sastra tersebut, memungkinkan peneliti untuk mencari hubungan-hubungan sastra dengan kenyataan. Selain itu, dalam kajian sastra dari segi sosiologis tersebut, peneliti dapat pula mengkaji cerminan-cerminan kenyatan yang terdapat dalam karya sastra.

Pembahasan mengenai realitas sosial yang tampak dalam karya sastra sudah banyak dilakukan oleh peneliti lain. Pembahasan mengenai jenis realitas sosial itu pun beragam bentuknya. Ada peneliti yang fokus pada realitas kemiskinan (Sulistiyana, 2014). Realitas kemiskinan tersebut adalah realita kemiskinan yang ditemukan pada novel Jatisaba karya Ramayda Akmal. Ada peneliti yang lebih memilih untuk berfokus pada konfllik sosial (Sipayung, 2016). Konflik sosial yang dibahas tersebut adalah konflik sosial yang muncul pada novel Maryam karya Okky Madasari. Ada pula peneliti yang berfokus pada aspek sosial karya sastra tersebut (Juliansyah, Arifin, \& Rokhmansyah, 2018). Fokus penelitian aspek sosial karya sastra tersebut diterapkan untuk meneliti novel Ada Surga di Rumahmu karya Oka Aurora. Selain contoh-contoh tersebut, tentu saja masih ada banyak kajian lain yang secara khusus memfokuskan pada bidang realitas sosial.

Pandemi covid-19 sendiri, walaupun merupakan fenomena yang terbilang baru, sejauh ini sudah cukup banyak menyita perhatian para peneliti dari berbagai bidang ilmu. Tidak sedikit kajian tentang feomena pandemi tersebut yang muncul dari sudut pandang agama, sosial, politik, ekonomi, pendidikan, dan sudut pandang lainnya. Putra, (2020) memaparkan pendapatnya tentang refleksi atas sistem ekonomi pada masa pandemi covid-19. Kajian dalam bidang agama, salah satunya, ditulis oleh Lestari (2021), yang berfokus pada masalah kematangan beragama di era pandemi. Telaah kritis pandemi covid-19 pada bidang pendidikan juga telah banyak dilakukan oleh peneliti, salah satunya oleh Ichsan (2020). Adapun kajiankajian dalam bidang kesehatan yang terdampak langsung pandemi sangatalah banyak, salah satu contohnya kajian tentang pelaksanaan disinfeksi sebagai salah satu upaya pencegahan covid-19 dan potensi risiko kesehatan di Indonesia (Athena et al., 2020).

Berdasarkan uraian di atas dapat ditarik sebuah simpulan bahwa analisis realitas sosial pada masa pandemi covid-19 yang terepresentasikan pada karya sastra belum banyak dilakukan. Hal itu karena memang fenomena pandemi covid19 merupakan sebuah fenomena baru. Penelitian sastra dengan objek karya sastra bertemakan pandemi, secara keilmuan, tentu saja aka menambah kekayaan khazanah penelitian sastra itu sendiri. Selain itu, penelitian ini akan bermanfat dalam mengembangkan ilmu sosiologi sastra. Secara praktis, analisisis ini diharapkan mampu membantu pembaca untuk menemukan realitas sosial pada masa pandemi covid-19 yang tercermin dalam karya sastra. Hal itu dapat dijadikan sebagai sarana untuk merefleksikan kompleksitas kehidupan yang tercermin dalam karya sastra. Selain itu, penelitian ini diharapkan dapat dimanfaatkan oleh para peneliti lain untuk dijadikan sebagai salah satu sumber referensi yang dapat dijadikan acuan penelitian. 


\author{
Indonesian Language Education and Literature \\ e-ISSN: 2502-2261 \\ http://www.syekhnurjati.ac.id/jurnal/index.php/jeill/ \\ Vol. 6, No. 2, Juli 2021, $336-350$
}

\title{
METODE
}

Penelitian ini dapat digolongkan ke dalam jenis penelitian deskriptif kualitatif. Dalam penelitian ini dideskipsikan dan dianalisis realitas sosial yang ada pada cerpen Atai Balak dan Rencana Lebaran Korona. Penelitian dilakukan pada bulan Juni-Desember 2020. Peneliti memanfaatkan pendekatan sosiologi sastra dalam menganalisis cerpen tersebut. Sumber data dalam penelitian ini adalah cerpen Atai Balak dan Rencana Lebaran Korona karya Guntur Alam. Cerpen tersebut dimuat pada media massa elektronik JawaPos.com tanggal 31 Mei 2020. Adapun data penelitian berupa kalimat-kalimat dalam cerpen yang memuat fenomena-fenomena realitas sosial.

Pengumpulan data dilakukan dengan prosedur observasi, yaitu dengan mengobservasi berbagai kalimat-kalimat dalam cerpen yang memuat realitas sosial. Teknik simak dan teknik catat juga dimanfaatkan peneliti dalam pengumpulan data. Peneliti melakukan penyimakan dan pencatatan penggunaan bahasa yang tertulis dalam cerpen sebagai data penelitian. Menurut Faruk (2012), teknik pengumpulan data harus dapat digunakan secara efektif dan efisien. Data verbal dapat diperoleh dengan teknik simak yang sepadan dengan observasi. Teknik simak dalam hal ini digunakan untuk penyimakan data secara tertulis yang berupa fenomena relitas sosial. Oleh karena itu, untuk mendapatkan data dalam penelitian ini, peneliti menggunakan teknik simak yang dilanjutkan dengan teknik catat. Sesuai dengan jenis penelitian, yaitu kualitatif, peneliti bertindak sebagai instrumen utama. Hal ini karena peneliti sendirilah yang bertindak dalam mengumpulkan data. Selain itu, peneliti juga memanfaatkan kartu data sebagai instrumen pendukung. Validasi data dilakukan dengan cara trianggulasi ahli untuk mengecek keabsahan data.

Analisis data dilakukan dengan metode analisis isi dan pendekatan sosiologi sastra. Dalam hal ini, peneliti menganalisis isi cerpen untuk dapat mengungkapkan fenomena sosial yang terdapat di dalamnya. Langkah pertama yang dilakukan oleh peneliti dalam analisis data, yaitu menyeleksi data-data yang terdapat dalam kartu data kemudian mengklasifikasikan berdasarkan jenis realitas sosial yang terdapat di dalamnya. Langkah kedua ialah menyajikan data dengan menganalisisnya berdasarkan pendekatan sosiologi sastra (berfokus pada realitas sosial yang ditemukan dalam cerpen). Lahkah terakhir, yaitu menarik simpulan berdasarkan proses analisis realitas sosial yang telah dilakukan. Hasil simpulan tersebut kemudian dideskripsikan secara tertulis.

\section{HASIL DAN PEMBAHASAN}

Pada bagian ini, akan dipaparkan hasil penelitian dan pembahasan berdasarkan analisis yang telah dilakukan terhadap cerpen Atai Balak dan Rencana Lebaran Korona. Berdasarkan analisis dengan pendekatan sosiologi sastra tersebut, secara khusus ada tiga hal yang hendak dipaparkan pada subbab hasil dan pembahasan ini. Ketiga hal tersebut meliputi: 1) karya sastras sebagai cerminan kenyataan, 2) tokoh Atai Balak sebagai representasi masyarakat kalangan bawah, dan 3) realitas sosial dalam cerpen Atai Balak dan Rencana Lebaran Korona.

\section{Karya Sasta sebagai Cerminan Kenyataan}

Sebagai bagian dari anggota masyarakat, sering seorang pengarang menjadikan fenomena-fenomena yang terjadi dalam kehidupan nyata sebagai sumber cerita. Fenomena-fenomena sosial yang terjadi secara nyata di masyarakat itu yang selanjutnya dipadukan dengan imajinasi pengarang membuat sebuah cerita 
menjadi lebih berkesan, lebih hidup, dan lebih bermakna. Kesan dan makna mendalam yang dapat ditangkap oleh pembaca melalui cerita yang ditampilkan, tidak boleh dilepaskan dari peran utama dan kelihaian pengarang dalam menyajikan cerita. Jika mengikuti pendapat yang disampaikan oleh Nurhadi \& Adriyanti (2020), pengarang mempunyai kekuatan dalam menampilkan cerita.

Kekuatan pengarang dalam menampilkan cerita seperti disinggung di atas, tampak juga dalam cerpen Atai Balak dan Rencana Lebaran Korona. Sebagai seorang yang lahir di tanah Sumatera, yaitu Sumatera Selatan, Guntur Alam, penulis cerpen ini, mencoba untuk memotret realitas sosial di tanah kelahirannya ketika pandemi covid-19 melanda. Dengan memilih latar kota Palembang, cerpen ini seolah-olah benar-benar menjadi cermin situasi yang terjadi sebagai akibat atas adanya pandemi di kota itu.

ATAI Balak meringkuk di bawah Jembatan Ampera. Hanya berjarak kurang dari seratus meter, Pasar 16 Ilir Kota Palembang berdiri tegar dalam guyuran hujan deras. Laki-laki bertubuh kerempeng dengan rambut keriting itu melirik jam di pergelangan tangan kirinya. Embun membuat jarum jam itu terlihat kurang jelas. Atai Balak sedikit memicingkan matanya, sudah pukul delapan belas lewat. Perutnya kembali melilit. Perih. Tadi dia sudah menadahkan tangan pada air hujan untuk berbuka puasa, meneguknya untuk sedikit menghalau rasa lapar. Namun, sia-sia. Sebanyak apa pun dia minum, perutnya masih akan tetap lapar.

Kutipan di atas merupakan bukti bahwa cerpen yang ditulis oleh Guntur Alam ini benar-benar berlatarkan kota Palembang, salah satu kota di Indonesia yang juga terimbas pandemi. Secara lebih spesifik, kutipan di atas mengambil latar Jembatan Ampera dan Pasar 16 Ilir. Dari segi geografis, Kota Palembang dipisahkan oleh sungai Musi menjadi wilayah Ilir (di sebelah utara sungai) dan wilayah Ulu (di sebelah selatan sungai). Untuk menjembatani berbagai kepentingan dua wilayah tersebut, dibangunlah Jembatan Ampera di tengah kota yang kini bolehlah disebut sebagai ikon kota Palembang itu sendiri (Sholeh \& Nindiati, 2018). Adapun Pasar 16 Ilir saat ini telah menjadi pusat grosir di kota Palembang. Lokasi pasar yang strategis di bawah Jembatan Ampera memudahkan masyarakat dari wilayah Ilir dan wilayah Ulu untuk menjangkaunya sehingga pasar tersebut selalu ramai dan mudah berkembang secara pesat (Anggarini et al., 2020).

Pemilihan latar jantung kota Palembang oleh Guntur Alam tersebut tentu saja telah melewati berbagai pertimbangan yang masak. Jika ditelisik lebih seksama, pusat kota yang menawarkan segala kemegahan, kemajuan, dan kemodernan selalu saja menyimpan satu sisi kerapuhan. Selalu ada sebuah kontadiksi dalam kemajuan tersebut yang diwakili oleh kaum menengah ke bawah yang tidak dapat mengikuti dan mengimbangi kemajuan tersebut. Mereka akan selalu menjadi yang tertinggal.

Situasi tersebut, secara konkret, dalam cerpen ini direpresentasikan melalui sepenggal kisah hidup seorang tokoh bernama Atai Balak. Ia digambarkan memiliki pekerjaan dengan upah yang tidak tetap, sebuah pekerjaan yang sangat rentan terdampak pandemi. Fakta yang memang tidak dapat ditampik bahwa kelompok pekerja harian lepas dengan upah yang tidak tetap seperti Atau Balak sangat 
berpotensi terkena imbas langsung atas pandemi yang terjadi (Yamali \& Putri, 2020).

Cerminan kenyataan lain yang tergambar dalam cerpen ini, yaitu tentang cara pandang dan sikap masyarakat Indonesia terhadap salah satu hari besar keagamaan, yaitu Idul Fitri. Hari raya yang biasa dikenal dengan istilah lebaran itu tidak hanya sekadar hari raya, tetapi juga terlebih itu lebaran telah menjadi sebuah tradisi dan menjadi sebuah budaya. Lebaran selalu ditunggu. Lebaran selalu menjadi suatu euforia tersediri bagi setiap elemen masyarakat, atau bahkan mungkin juga menjadi suatu hal yang memberikan kesan secara mendalam dan sulit dilupakan oleh mayoritas masyarakat Indonesia. Namun, lebaran di tengah pandemi membawa suatu permasalahan tersendiri (Utami, 2020).

Permasalahan itu dialami juga oleh tokoh Atai Balak. Ada sebuah dampak buruk ketika suatu hal baik seperti lebaran seolah telah menjadi suatu tradisi. Mungkin seperti itulah kurang lebih gambaran situasi yang sedang dihadapi oleh Atai Balak. Ia tidak siap menghadapi lebaran di tengah pandemi, terutama ia tidak siap untuk memenuhi permintaan anak-anak asuhnya yang sudah tebiasa dengan baju baru dan berbagai hal lain yang mewarnai nuansa lebaran. Atai Balak harus dibenturkan dengan kenyataan bahwa lebaran mereka kali ini berbeda dan hal itu bukanlah menjadi hal yang mudah untuk dimengerti dan diterima oleh anak-anak asuhnya. Situasi itu, secara singkat dapat dilihat melalui kutipan-kutipan di bawah ini.

Apa yang harus diceritakan kepada anak-anak? Hatinya bertanya. Untuk orang-orang tua, Atai Balak tahu mereka tidak butuh baju Lebaran. Lima manula yang dia urus hanya butuh tempat berteduh, makan-minum, dan hangatnya keluarga. Mereka tidak pernah meminta lebih dari itu. Sementara anak-anak? Bukan ingin meminta lebih, tapi karena mereka masih anakanak, bila Lebaran datang, artinya mereka punya baju baru.

Tadi pagi Rizki, anak yatim piatu yang dia temukan di Pasar 16 Ilir ketika berumur enam tahun, bertanya kepadanya, "Bang, kita benar-benar tidak beli baju Lebaran tahun ini?"

"Tahun ini," ujar Atai Balak, "Abang tak dapat membelikan kalian baju Lebaran. Parkiran sepi. Toko-toko di Pasar 16 Ilir tutup semua. Korona tidak hanya meliburkan sekolah kalian, tapi juga pasar."

Dalam kutipan-kutipan di atas telihat bahwa sebagai orang yang masuk kelompok masyarakat terimbas pandemi, Atai Balak tidak dapat mengabulkan permintaan anak-anak asuhnya. Tentu saja hal itu menumbuhkan rasa kecewa pada diri anak-anak itu. Orang tua mana yang tidak akan tergores hatinya tatkala ia telah mengecewakan anaknya. Permasalahan yang dihadapi Atai Balak itu sekaligus seolah menjadi sebuah refleksi atas situasi yang terjadi pada kelompok masyarakat rentan seperti itu di tengah pandemi seperti ini.

\section{Tokoh Atai Balak sebagai Representasi Masyarakat Kalangan Bawah}

Selain sebagai pusat perdagangan dan ekonomi, pasar seringkali juga menjadi pusat tindakan kriminalitas. Layaknya sebuah mata uang dengan dua sisi yang berbeda, pasar dan kejahatan akan selalu terhubung. Kemudahakan untuk 
mengakses pasar oleh berbagai kalangan dan kemudahan bertransaksi, khusunya di pasar tradisional, di satu sisi, justru menjadikan pasar sangatlah rawan tindak kejahatan.

Sisi rapuh Pasar 16 Ilir dalam cerpen ini seperti telah disinggung sebelumnya, justru terepresentasikan pada diri Atai Balak sebagai tokoh utama. Atai Balak menjadi representasi masyarakat kalangan bawah di tengah majunya perekonomian pusat kota dan secara khusus pada situasi pandemi. Namun, tidak hanya sisi rapuh, Atai Balak juga mewakili sisi gelap pasar yang rawan dengan kekerasan dan kejahatan (Musyarafah \& Lukmawati, 2019). Secara lebih rinci, hal itu dapat dilihat pada kutipan-kutipan di bawah ini.

"Kenapa pula dibatasi?" dengus Atai Balak. Dia menggaruk-garuk rambut keritingnya, gatal dan kesal. Atai Balak sudah berkeliling mengecek semua lahan parkir yang dia kuasai di wilayah Pasar 16 Ilir. Semua bernasib sama. Kosong melompong.

Atai Balak menghela napas. Hari ini parkiran kosong melompong. Dari tokotoko yang biasanya juga memberi uang keamanan, tidak ada satu pun yang menyetor. Bagaimana mau menyetor, buka saja tidak.

Mat Jail tidak berkomentar. Laki-laki yang sudah dua kali masuk penjara itu tahu, bosnya itu tengah pening kepala. Mungkin tak banyak yang tahu, selain anak buahnya di Pasar 16 ini, Atai Balak mengasuh beberapa anak yatim piatu dan manula. Semua ditampung di rumahnya, daerah Pakjo sana. Melihat tampang Atai Balak yang seram; bekas luka codet di pipi kanan, tato memenuhi leher, gigi menguning oleh tembakau, bibir hitam legam, siapa sangka laki-laki sangar itu punya hati yang peka. Mat Jail merasakan sendiri kebaikan Atai Balak. Selepas dia keluar dari penjara karena kasus pembunuhan, tak ada siapa pun yang mau menampungnya. Dia bisa mati kelaparan jika Atai Balak tak mengulurkan tangan kepadanya.

Berdasarkan kutipan-kutipan di atas, secara lebih mudah, dapat dikatakan bahwa Atai Balak merupakan seorang preman pasar. Dia digambarkan memiliki kekuasaan dan kekuasaan itulah sumber mata pencahariannya. Diceritakan bahwa dia menguasai lahan parkir di wilayah Pasar 16 Ilir dan juga pertokoan di wilayah itu yang biasa menyetor uang keamanan kepadanya. Sebagai seorang yang memiliki kekuasaan, dalam cerpen itu, Atai Balak memiliki anak buah yang bernama Mat Jail yang ternyata meruoaka seorang residivis.

Penggambaran fisik sosok Atai Balak semakin mencerminkan seorang preman pasar yang sesungguhnya. Atai Balak digambarkan memiliki tampang seram, bekas luka codet di pipi kanan, tato memenuhi leher, gigi kuning akibat merokok, dan bibir hitam legam. Hubungannya dengan Mat Jail yang mantan seorah pembunuh juga semakin menegaskan pekerjaannya sebagai seorang preman pasar.

Penggambaran secara fisik, hubungan sosial dengan orang yang satu perkerjaan dengannya, serta kekuasaan yang dimiliki di pasar yang terepresentasi dalam diri tokoh Atai Balak sungguh-sungguh menjadi cermin realita atas sisi gelap kehidupan kalangan bawah khususnya preman pasar. Melalui sosok tokoh Atai Balak itu pula, Guntur Alam sebagai pengarang cerpen seolah ingin mengenalkan 
pekerjaan sebagai preman pasar. Sebuah pekerjaan yang dalam dunia nyata ini identik dan dekat dengan dunia kriminal. Pekerjaan yang dalam situasi pandemi ini jelas-jelas akan sangat mudah terdampak karena mereka yang bekerja sebagai preman pasar tersebut dapat digolongkan sebagai kelompok orang dengan upah harian lepas.

Sangat jelas pula bahwa pekerjaan yang dilakoni oleh Atai Balai dilatarbelakangi oleh faktor ekonomi. Preman pasar, kriminalitas, dan faktor ekonomi seolah saling kait-mengkait (Masfiatun, 2019). Latar belakang faktor ekonomi tersebut dapat dijumpai juga pada tokoh Atai Balak, seperti tergambar pada kutipan di bawah ini.

Dalam benaknya lagi, anak-anak itu hanya mengangguk dengan muka lesu. Atai Balak tak pernah suka melihat wajah-wajah sedih. Bila melihat wajah sedih, dia teringat pada wajah almarhum adiknya dulu. Saban adiknya itu kepengin makan ayam goreng, kepengin baju baru, kepengin mainan baru, orang tua mereka tak pernah bisa memberikannya. Atai Balak memendam rasa marah. Dia marah pada ketidakmampuan dirinya dan orang tuanya untuk mewujudkan keinginan adiknya. Sampai pada satu titik, adiknya sakit dan orang tuanya tidak mampu membawanya berobat. Bila melihat anakanak telantar di Pasar 16 Ilir, Atai Balak selalu ditarik ingatan pada wajah adiknya yang sedih.

Kutipan di atas menunjukkan bahwa Atai Balak sejak awal memang terlahir dari keluarga miskin. Latar belakang ekonomi keluarganya sangatlah tidak baik. Orang tuanya dan juga dirinya tidak pernah dapat memenuhi keinginan adiknya. Bahkan, yang paling fatal, mereka tidak mampu membiayai adiknya untuk berobat.

Namun, latar belakang ekonomi dan pengalaman hidupnya tersebut justru menjadikan Atai Balak seorang pribadi yang mempunyai solidaritas tinggi. Preman pasar yang identik dengan tindak kejahatan dan kriminalitas jutrru sama sekali tidak tergambar dalam kepribadian tokoh Atai Balak. Pekerjan preman pasar dilakoninya murni karena desakan ekonomi. Seperti tampak pada kutipan-kutipan sebelumnya di atas, Atai Balak diceritakan menampung anak yatim piatu dan manula di rumahnya. Kutipan-kutipan di bawah ini dapat menambahkan juga penggambaran sisi humanis tokoh Atai Balak.

HUJAN masih turun dengan deras, Atai Balak mengisap rokok terakhir dengan sangat pelan. Dia berusaha menikmati harta terakhirnya itu. Mat Jail belum ada tanda-tanda muncul. Tadi, jelang berbuka puasa, sekitar pukul tujuh belas, Atai Balak meminta Mat Jail dan Kuyung untuk pulang ke rumah sebentar, membawa makanan berbuka untuk anak yatim piatu dan manula yang diurusnya. Mereka semua orang-orang terbuang. Anak-anak yang tak diinginkan orang tua mereka dan orang-orang tua yang tak diingat lagi oleh anak-anak mereka.

Atai Balak hanya menyeringai saat bocah laki-laki yang kini berusia sembilan tahun itu bertanya. Dia menyembunyikan air mata yang menghangat di sudut matanya. Semua anak-anak di sini memanggilnya abang. Sejak sekolah diliburkan karena korona, Rizki dan beberapa anak asuhnya meminta izin kepada Atai Balak untuk pergi mencari uang. Mengamen atau mengemis. Namun, Atai Balak melarang. Dia tidak ingin 
anak-anak itu berurusan dengan dinas sosial dan kerasnya jalanan. Terlebih, sangat repot mengurus bila mereka tertangkap petugas. Selalu butuh uang agar anak-anak bisa kembali ke rumah.

Kerasnya kehidupan karena keterbelakangan di bidang ekonomi memang sering kali di satu sisi justru menumbuhkan semangat solidaritas dan kepedulian yang tinggi. Realita tersebut ditemukan juga pada diri Atai Balak seperti tampak pada kutipan di atas. Atai Balak merupakan pribadi yang memiliki kepedulian tinggi terhadap orang-orang yang terbuang dan tidak diakui oleh keluarganya. Ia tidak pernah mengizinkan orang-orang itu untuk mengenal kerasanya kehidupan di jalanan. Ia juga tidak pernah mau melibatkan mereka dalam sebuah masalah.

Pada situasi pandemi, kekuasaan sebagai preman pasar yang dimiliki oleh Atai Balak tidak berarti apa-apa. Ia tidak dapat menunjukkan taringnya untuk menakklukkan masalah dan situasi yang dihadapinya saat ini. Hal yang dapat dilakukannya hanyalah berharap dan berandai-andai korona lekas usai.

Sejak siang, Atai Balak menyusun rencana manis jika korona usai. Jika parkiran motor dan mobil di bawah Jembatan Ampera ini kembali ramai dan sesak, jika toko-toko di Pasar 16 Ilir kembali ramai oleh pembeli, jika penghasilan Atai Balak dan anak-anak buahnya kembali seperti sediakala. Jika... Atai Balak merasa kata itu terdengar penuh harapan. Namun, dia kembali bertanya, kapan kata "jika" itu bisa terlaksanakan?

Harapan Atai Balak seperti tercermin pada kutipan di atas sebenarnya mewakili harapan semua orang terutama kalangan bawah yang terepresentasi pada tokoh Atai Balak. Semua orang berharap pandemi segera berakhir. Semua berharap kondisi kembali normal. Semua orang memiliki impian-impian yang ingin diwujudkan jika pandemi ini berakhir. Namun, melihat kenyataan di lapangan, yaitu semakin bertambangnya kasus orang yang terpapar korona membuat harapanharapan dan impian-impian tadi seolah sangat mustahil untuk diwujudkan dalam waktu dekat ini.

"Tapi, Abang janji," ucapnya cepat-cepat, berusaha menghalau kesedihan di wajah anak-anak itu. "Usai korona ini, kalau Pasar 16 Ilir sudah dibuka lagi dan abang dapat duit, kalian semua akan abang belikan baju. Dua tiaptiap orang."

Di benaknya lagi, anak-anak itu mengangkat wajah, tersenyum semringah kala mendengar kata-kata "dua tiap orang". Atai Balak tersenyum senang. Rencananya terdengar cukup sempurna. Dia mengangguk-angguk. Dia yakin, anak-anak akan senang mendengar rencananya. Tak apa tidak berbaju Lebaran di Idul Fitri tahun ini. Tapi, seusai korona, mereka bisa membeli dua baju Lebaran sekaligus. Hanya berjarak dua bulan usai Idul Fitri, akan ada Idul Adha. Anggaplah baju baru itu untuk Lebaran Haji.

Ya, ya, ya, sebuah rencana yang sempurna, ucap hati Atai Balak.

Rencana Atai Balak seperti tergambar pada kutipan di atas sebenarnya cukuplah sederhana. Ia hanya ingin membelikan baju untuk anak-anak asuhnya. Namun, rencana itu ternyata sangatlah sulit untuk diwujudkan. Ia hanya dapat berharap Pasar 16 Ilir, sumber mata pencahariannya segera dibuka kembali karena itulah satu-satunya harapan untuk mendapatkan uang. Uang itulah yang akan digunakannya untuk membelikan anak-anak itu baju baru, dua pasang setiap orang. 
Karena Idul Fitri kali ini berbeda, Atai Balak hanya dapat memberikan janji pada anak-anak itu. Atai Balak tidak dapat memberikan baju baru saat lebaran. Namun, ia berjanji akan memberikan baju saat Idul Adha atau Lebaran Haji. Dia berjanji untuk memberikan baju dua pasang sebagai ganti tidak adanya baju baru di hari lebaran. Akan tetapi, janji dan rencanyanya teresebut hanya akan dapat diwujudkan ketika korona telah usai.

\section{Realitas Sosial dalam Cerpen Atai Balak dan Rencana Lebaran Korona}

Pandemi covid-19 dalam waktu singkat telah mengubah tatanan kehidupan yang selama ini dianggap mapan. Di Indonesia, pandemi ini berdampak pada berbagai bidang kehidupan sosial seperti pendidikan, agama, ekonomi, dan politik (Agung, 2020). Dalam bidang ekonomi, pandemi covid-19 di Indonesia berdampak pada sulitnya mencari pekerjaan dan pemenuhan kebutuhan hidup sehari-hari (Sugiri, 2020).

Untuk meminimalkan berbagai permasalahan yang terjadi akibat imbas pandemi covid-19 tersebut, berbagai langkah dan kebijakan pun diambil oleh pemerintah Indonesia. Karantina wilayah, social distancing, dan physical distancing merupakan langkah-langkah yang telah diambil oleh pemerintah guna mengendalikan angka penambahan kasus akibat terpapar corona virus (Herdiana, 2020). Selain itu, pemerintah juga menerapkan kebijakan hukum Pembatasan Sosial Berskala Besar (PSBB) Dalam Rangka Percepatan Penanganan Corona Virus Disease 2019 (Fauzi, 2020; Hairi, 2020; Saraswati, 2020).

Namun, efektivitas langkah-langkah dan kebijakan yang diambil pemerintah seperti di atas banyak dipertanyakan. Muncul kubu pro kontra terhadap kebijakan yang diambil oleh pemerintah tersebut. Ada berbagai dampak dan imbas lain atas kebijakan-kebijakan yang diterapkan oleh pemerintah tersebut (Ristyawati, 2020; Wijayanto, 2020)

Salah satu dampak adanya PSBB seperti tergambar dalam cerpen Atai Balak dan Rencana Lebaran Korona adalah dampak pada bidang ekonomi. Adanya berbagai pembatasan kegiatan mengakibatkan lumpuhnya perekonomian nasional. Dampak itu dirasakan juga oleh Atai Balak seperti pada kutipan-kutipan di bawah ini.

"Palembang menerapkan PSBB, Bang." Itu ucapan Mat Jail ketika Atai Balak terheran-heran melihat Pasar 16 Ilir yang sudah seperti tanah kuburan.

"Apa itu PSBB, Mat?" tanyanya.

"Pembatasan sosial berskala besar, Bang." Mat Jail menjawab sambil merapikan uang dua ribu yang hanya empat lembar. Lahan parkir yang dia jaga kosong melompong. Padahal, ruang terbuka hijau yang ada di samping Jembatan Ampera ini biasanya selalu penuh sesak oleh motor dan mobil yang parkir.

"Kenapa pula dibatasi?" dengus Atai Balak. Dia menggaruk-garuk rambut keritingnya, gatal dan kesal. Atai Balak sudah berkeliling mengecek semua lahan parkir yang dia kuasai di wilayah Pasar 16 Ilir. Semua bernasib sama. Kosong melompong. 
"Gara-gara korona, Bang," terang Mat Jail lagi. Laki-laki pendek bertubuh gempal dengan tato memenuhi kedua lengan itu berdiri dari duduknya. "Semakin banyak saja korban korona di Palembang. Dengar-dengar, sudah seratus orang lebih. Katanya, wali kota takut kalau-kalau ada yang kena korona belanja ke 16. Bisa mati semua orang di sini."

"Ah, akal-akalan," gerutu Atai Balak. "Kalau waktunya mati, ya mati saja. Mau terkena korona atau cuma bisul, sama saja."

Hari ini sudah puasa Ramadan hari kedua puluh tiga. Seminggu lagi Idul Fitri. Seharusnya Pasar 16 Ilir sedang ramai-ramainya. Orang-orang akan berjejal, berdesak- desakan, untuk membeli baju dan kue Lebaran. Namun, tidak tahun ini. Sejak awal puasa, toko-toko di sini dipaksa tutup. Orangorang juga dilarang berbelanja.

Pada kutipan-kutipan di atas terlihat bahwa kebijakan PSBB sangat terasa dampaknya bagi Atai Balak. Dengan statusnya sebagai seorang pekerja harian lepas, PSBB sama sekali tidak menguntungkannya. Adanya berbagai larangan sebagai akibat diberlakukannya PSBB, misalnya penutupan toko-toko dan larangan berbelanja seperti tergambar pada kutipan di atas, benar-benar merugikannya.

Bagi orang lain dan juga para pengambil kebijakan, mungkin PSBB tersebut dipandang cukup efektif dalam memutus mata rantai penyebaran corona virus. Itulah sebabnya, beberapa kota besar di Indonesia dengan tingkat penyebaran corona virus yang tinggi mulai memberlakukan PSBB, termasuk Kota Palembang. Dalam kutipan di atas terlihat pula langkah kepala daerah, dalam hal ini wali kota, untuk melindungi warganya dari corona virus dengan penetapan PSBB. Namun, efektivitas kebijakan tersebut tidak belaku bagi Atai Balak. PSBB tersebut justru mematikan sumber mata pencaharianya.

Dalam kutipan-kutipan di atas tergambar pula ketidaktahuan Atai Balak tentang apa itu PSBB serta sikapnya yang cenderung sinis dan apatis menanggapi kebijakan tersebut. Sikap Atai Balak tersebut mencerminkan bagaimana kondisi realita yang terjadi pada masyarakat kalangan bawah terhadap berbagai kebijakan yang diambil oleh pemerintah untuk menanggulangi pandemi. Entah karena memang kurangnya edukasi dan sosialisasi dari para pemangku kepentigan dan pengambil kebijakan, atau entah karena memang masyarakat itu sendirilah yang banyak tertinggal informasi. Kebijakan-kebijakan seperti itu tadi selalu menimbulkan keberagaman sikap di masyarakat, salah satunya terepresentasikan melalui tokoh Atai Balak.

Sikap apatis dan sinis seperti yang dilakukan oleh tokoh Atai Balak, jika ditelusur lebih lanjut bukan tanpa sebab. Kebijakan itu tenyata memang seolah mencekik dirinya dan membuatnya mati secara perlahan. Hal itu dapat dilihat melalui kutipan-kutipan di bawah ini.

Atai Balak menghela napas. Hari ini parkiran kosong melompong. Dari tokotoko yang biasanya juga memberi uang keamanan, tidak ada satu pun yang menyetor. Bagaimana mau menyetor, buka saja tidak. Bahkan tadi, untuk membeli makanan buka puasa hari ini, Atai Balak terpaksa menarik sisa uang yang ada di ATM-nya. Sejak PSBB, setiap hari Atai Balak menggerus uang tabungannya. Dan, hari ini uang itu benar-benar habis. 
Laki-laki berambut keriting itu meringis. Usai rencana yang sempurna tadi, dia ditampar kenyataan paling pahit. Dia belum makan apa pun, padahal hari sudah hampir jam delapan malam. Uang di ATM-nya sudah terkuras habis. Lalu, bagaimana anak-anak itu makan sahur besok pagi? Bagaimana dengan makanan berbuka mereka? Setelah nyaris satu bulan PSBB, Atai Balak tak mendapat penghasilan apa pun. Laki-laki itu baru menyadari, dia tidak butuh rencana seusai Covid-19 mereda, tapi butuh rencana baik sekarang. Makan apa mereka besok pagi? Atai Balak melirik jam butut di tangannya. Bila dijual, laku berapa? Batinnya. Mata Atai Balak terasa memanas, dia teringat wajah sedih almarhum adiknya.

Berbagai bantuan yang ditawarkan pemerintah bagi masyarakat yang terdampak pandemi ternyata tidak selalu menjadi solusi, Ketidakmerataan dan ketidakadilan dalam menyalurkan bantuan, menjadi salah satu faktor penghambat program baik pemerintah tersebut. Pada faktanya, di tengah berbagai bantuan yang terus disalurkan oleh pemerintah, tetap ada beberapa orang yang harus tetap berjuang sendiri tanpa tersentuh bantuan dari siapa pun, seperti terepresentasi pada tokoh Atai Balak di atas.

ATAI Balak meringkuk di bawah Jembatan Ampera. Hanya berjarak kurang dari seratus meter, Pasar 16 Ilir Kota Palembang berdiri tegar dalam guyuran hujan deras. Laki-laki bertubuh kerempeng dengan rambut keriting itu melirik jam di pergelangan tangan kirinya. Embun membuat jarum jam itu terlihat kurang jelas. Atai Balak sedikit memicingkan matanya, sudah pukul delapan belas lewat. Perutnya kembali melilit. Perih. Tadi dia sudah menadahkan tangan pada air hujan untuk berbuka puasa, meneguknya untuk sedikit menghalau rasa lapar. Namun, sia-sia. Sebanyak apa pun dia minum, perutnya masih akan tetap lapar.

Kesenjangan sosial yang selalu menjadi permasalahan dalam berbagai dimensi waktu, semakin menciptakan jurang pemisah yang sangat dalam pada masa pandemi. Tingginya angka pengangguran dan semakin meningkatnya angka kemiskinan menjadi fenomena yang seolah sudah sewajarnya (Fahri et al., 2019). Ketika di satu sisi ada beberapa pihak yang secara ekonomi sama sekali tidak terpengaruh dampak pandemi, di sisi lain ada pihak-pihak seperti tokoh Atai Balak yang harus mati-matian berjuang untuk dapat makan. Ia yang pada dasarnya sudah miskin menjadi semakin miskin akibat pandemi sehingga melonjaklah angka kemiskinan di Indonesia.

\section{SIMPULAN}

Dari paparan pembahasan di atas dapat ditarik sebuah simpulan bahwa karya sastra memiliki keterkaitan erat dengan kenyataan. Fenomena pandemi ternyata banyak menarik perhatian sastrawan sebagai bahan penulisan karya sastra. Salah satu contoh karya sastra yang bertemankan pandemi ini adalah cerpen Atai Balak dan Rencana Lebran Korona yang ditulis oleh Guntur Alam. Refleksi atas realitas sosial yang terjadi pada masa pandemi terepresentasikan melalaui tokoh Atai Balak dengan segala permasalahan kehidupan yang melingkupnya. Dalam cerpen tersebut nuansa reealita sosial yang tercermin dalam karya sastra sangatlah kental. Tokoh Atai Balak dapat menjadi representasi masyarakat kalangan bawah dalam 
menghadapi pandemi. Realitas sosial pada masa pandemi yang dapat ditemukan dalam cerpen tersebut, yaitu terkait dengan kebijakan Pembatasan Sosial Berskala Besar (PSBB) dan realita kemiskinan yang semakin meningkat sebagai dampak atas adanya pandemi.

\section{DAFTAR PUSTAKA}

Abrams, \& Harpham. (2011). A Glossary of Literary Terms . Cengage Learning Google Books. https://www.google.co.id/books/edition/A_Glossary_of_Literary_Terms/2_ Z-cgAACAAJ?hl=id

Agung, I. M. (2020). Memahami Pandemi Covid-19 Dalam Perspektif Psikologi Sosial. Psikobuletin:Buletin Ilmiah Psikologi, 1(2), 68-84. http://ejournal.uinsuska.ac.id/index.php/Psikobuletin/article/view/9616/5058

Anggarini, V., Farida, F., \& Alian, A. (2020). Dinamika Pasar Sekanak di Kota Palembang 2010-2016. Jurnal Pattingalloang, 7(1), 12-22. https://doi.org/10.26858/pattingalloang.v7i1.12512

Athena, A., Laelasari, E., \& Puspita, T. (2020). Pelaksanaan Disinfeksi dalam Pencegahan Penularan Covid-19 dan Potensi Risiko Terhadap Kesehatan di Indonesia. Jurnal Ekologi Kesehatan, 19(1), 1-20. https://doi.org/10.22435/jek.v19i1.3146

Bruce, S. (2018). Sociology: A Very Short Introduction - Google Buku. https://books.google.co.id/books?hl=id\&lr=\&id=p0VvDwAAQBAJ\&oi=fn $\mathrm{d} \& \mathrm{pg}=\mathrm{PP} 1 \& \mathrm{dq}=$ sociology+of+literature+theory \&ots $=\mathrm{z} 2 \mathrm{li} 45 \mathrm{qd} 0 \& \operatorname{sig}=\mathrm{Vpw}$ yL0_Fk0TqVzMxCayUr8_oWII\&redir_esc=y\#v=onepage\&q=sociology of literature theory $\& \mathrm{f}=$ false.

Canton, J. (2016). The Literature Book: Big Ideas Simply Explained. London, Britania Raya: DK Publishing.

Emzir \& Rohman, S. (2015). Teori dan Pengajaran Sastra. Jakarta: Rajawali Press. Fahri, Jalil, \& Kasnelly. (2019). Meningkatnya Angka Pengangguran di Tengah Pandemi (Covid-19). Al-Misan: Jutnal Ekonomi Syariah ,2(2), 45-60.

Faruk. (2012). Metode Penelitian Sastra Sebuah Penjelajahan Awal. Yogyakarrta: Pustaka Pelajar.

Fauzi, A. (2020). Implementasi Pembatasan Sosial Berskala Besar, Sebuah Kebijakan Publik dalam Penanganan Pandemi Covid-19, JIANA (Jurnal Ilmu Administrasi Negara,, 16(1), 174-178.

Hairi, P. J. (2020). Implikasi Hukum Pembatasan Sosial Berskala Besar Terkait Pencegahan Covid-19. Info Singkat: Kajian Singkat terhadap Isu Aktual dan Strategis Bidang Hukum, XII(7), 1-6.

Herdiana, D. (2020). Implementasi Kebijakan Pembatasan Sosial Berskala Besar (PSBB) Sebagai Upaya Penanggulangan Corona Virus Disease 2019 (Covid19). Decision: Jurnal Administrasi Publik, 2(2), 1-14. DOI: http://dx.doi.org/10.23969/decision.v2i2.2978.

Ichsan. (2020). Pandemi Covid-19 dalam Telaah Kritis Sosiologi Pendidikan Ahmad Shofiyudin Ichsan. Jurnal Keguruan dan Ilmu Pendidikan, 7(2), 2020-2098. http://ejournal.unmus.ac.id/index.php/magistra.

Jabrohim. (2014). Teori Penelitian Sastra. Yogyakata: Pustaka Pelajar.

Juliansyah, J., Arifin, S., \& Rokhmansyah, A. (2018). Analisis Novel Ada Surga di 
Rumahmu Karya Oka Aurora Ditinjau dari Aspek Sosiologi Karya Sastra. Ilmu Budaya: Jurnal Bahasa, Sastra, Seni, dan Budaya, 2(4), 337-346.

Lestari, A. P. (2021). Kematangan Beragama Dalam Masa Pandemi Covid-19: Telaah Sosiologis Atas Nasihat Imam Besar Istiqlal Nasaruddin Umar. The Sociology of Islam, 1(1), 165-180. http://jurnalfisip.uinsby.ac.id/index.php/JSI/article/view/85.

Masfiatun, M. (2019). Pengaruh Faktor Ekonomi terhadap Jumlah Kejahatan (Crime Total) di Indonesia (2015-2017). Jurnal Keamanan Nasional, 5(2), 89-110. DOI: https://doi.org/10.31599/jkn.v5i2.437.

Mulyaningsih, I. (2015). Kajian Feminis Pada Novel "Ronggeng Dukuh Paruk" dan "Perempuan Berkalung Surban". Indonesian Language Education And Literature (ILEAL), 1(1), 107-119. DOI: 10.24235/ileal.v1i1.75.

Musyarafah, D \& Lukmawati, L. (2019). Perilaku Menyimpang pada Remaja Punk di Kawasan Pasar 16 Ilir Palembang. Jurnal Intelektualita: Keislaman, Sosial dan Sains, 7(2), 129-136.

Nurhadi, A., \& Adriyanti, N. (2020). Status Sosial Unsur Penokohan Pada Cerita Pendek "Sang Guru Juki" Karya Ahmad Tohari. Indonesian Language Education and Literature, 6(1), 119-127. https://doi.org/10.24235/ileal.v6i1.3816

Putra, S. D. E. (2020). (Pand) Economics: Refleksi atas Sistem Ekonomi di Masa Pandemi Covid-19. PINUS: Jurnal Penelitian Inovasi Pembelajaran, 5(2), 17-29.

Ristyawati, A. (2020). Efektifitas Kebijakan Pembatasan Sosial Berskala Besar Dalam Masa Pandemi Corona Virus 2019 oleh Pemerintah Sesuai Amanat UUD NRI Tahun 1945. Administrative Law and Governance Journal, 3(2), 240-249. https://doi.org/10.14710/alj.v3i2.240-249.

Saraswati, P. S. (2020). Kebijakan Hukum Terhadap Penanganan Pandemi Covid19 di Indonesia. Kertha Wicaksana, 14(2), 147-152. https://doi.org/10.22225/kw.14.2.1923.147-152

Sholeh, K., \& Nindiati, D. S. (2018). Eksistensi Jembatan Ampera terhadap Perkembangan Sosial, Budaya, dan Ekonomi Masyarakat Ulu Palembang Tahun 1950-2010. Jurnal HISTORIA, 6(2), 273-294.

Sipayung, M. E. (2016). Konflik Sosial dalam Novel Maryam Karya Okky Madasari: Kajian Sosiologi Sastra. In Sintesis, 10(1), 22-34.

Sugiri, D. (2020). Menyelamatkan Usaha Mikro, Kecil dan Menengah dari Dampak Pandemi Covid-19. Fokus Bisnis: Media Pengkajian Manajemen dan Akuntansi, 19(1), 76-86. https://doi.org/10.32639/fokusbisnis.v19i1.575.

Sulistiyana, P. (2014). Representasi Kemiskinan dalam Novel Jatisaba Karya Ramayda Akmal (Kajian Sosiologi Sastra). Bahtera Sastra: Antologi Bahasa dan Sastra Indonesia, 1(3), 1-12.

Utami, I. (2020). Tradisi Ramadahan dan Lebaran di Tengah Covid-19. Annizom, $5(2), 131-138$.

Wahyudi, T. (2013). Sosiologi Sastra Alan Swingewood Sebuah Teori. Poetika: Jurnal Ilmu Sastra, 1(1), 55-61.

Wijayanto, H. (2020). Menakar Efektivitas Pembatasan Sosial Berskala Besar dalam Penanggulangan Covid19. GEMA PUBLICA: Jurnal Manajemen dan Kebijakan Publik, 5(2), 98-106. https://doi.org/10.14710/gp.5.2.2020.98106. 


\section{Indonesian Language Education and Literature}

e-ISSN: 2502-2261

http://www.syekhnurjati.ac.id/jurnal/index.php/jeill/ Vol. 6, No. 2, Juli 2021, $336-350$

Yamali, F. R., \& Putri, R. N. (2020). Dampak Covid-19 Terhadap Ekonomi Indonesia. Ekonomis: Journal of Economics and Business, 4(2), 384-388. 